\title{
Peran Mediasi Kepuasan Kerja Pada Pengaruh Dukungan Organisasi Dan Lingkungan Kerja Terhadap Kinerja Pegawai Pada Kantor Dinas Ketahanan Pangan Dan Peternakan Provinsi Sumatera Utara
}

\author{
Hendra Sutrisno Marbun \\ Universitas Muhammadiyah Sumatera Utara Medan, Indonesia
}

\section{Jufrizen}

Universitas Muhammadiyah Sumatera Utara Medan, Indonesia

Koresponden: jufrizen@umsu.ac.id

\begin{abstract}
The purpose of this study was to examine and analyze the effect of organizational support and work environment on employee performance mediated by job satisfaction at the Office of Dinas Ketahanan Pangan dan Peternakan Provinsi Sumatera Utara directly or indirectly. The approach used in this study is a causal approach. The population in this study were all state civil servants at the Office of Dinas Ketahanan Pangan dan Peternakan Provinsi Sumatera Utara. The sample in this study used a sample of the slovin formula totaling 68 state civil servants at the Office of Dinas Ketahanan Pangan dan Peternakan Provinsi Sumatera Utara. Data collection techniques in this study used documentation, observation, and questionnaire techniques. The data analysis technique in this study uses a quantitative approach using statistical analysis by using the Auter Model Analysis test, Inner Model Analysis, and Hypothesis Testing. Data processing in this study using the PLS (Partial Least Square) software program. The results of this study prove that direct organizational support, work environment and job satisfaction have a significant effect on employee performance and indirectly organizational support and work environment have a significant effect on employee performance mediated by job satisfaction at the Office of Dinas Ketahanan Pangan dan Peternakan Provinsi Sumatera Utara.
\end{abstract}

Keywords Organizational Support, Work Environment, Job Satisfaction and Performance

\section{PENDAHULUAN}

Sumber daya manusia mempunyai arti penting karena manusia berperan aktif dan dominan dalam setiap kegiatan organisasi. Manusia dalam organisasi berperan sebagai penentu, pelaku dan perencana dalam mencapai tujuan organisasi sekaligus menentukan maju dan mundurnya organisasi. Manusia adalah sumber daya yang berbeda dari faktor produksi lainnya karena manusia mempunyai perasaan, pikiran, keinginan dan latar belakang yang heterogen. Manusia juga memiliki kebutuhan yang tidak terbatas, artinya kebutuhan manusia selalu bertambah dari waktu ke waktu. Kebutuhan manusia diartikan sebagai segala sesuatu yang dimilikinya, dicapai dan dinikmati, oleh karena itu manusia 
terdorong untuk melakukan aktivitas dengan bekerja. Rendahnya kualitas pelayanan publik merupakan salah satu sorotan yang diarahkan kepada birokrasi pemerintah dalam memberikan pelayanan kepada masyarakat. Perbaikan pelayanan publik di era reformasi merupakan harapan seluruh masyarakat, namun dalam perjalanannya ternyata tidak mengalami perubahan yang signifikan.

Berbagai tanggapan masyarakat justru cenderung menunjukkan bahwa berbagai jenis pelayanan publik mengalami kemunduran yang sebagian ditandai dengan banyaknya penyimpangan dalam layanan publik tersebut. Sistem dan prosedur pelayanan yang berbelit-belit dan sumber daya manusia yang lamban dalam memberikan pelayanan juga merupakan aspek layanan publik yang banyak disoroti. Instansi pemerintah pada prinsipnya harus menunjukkan kinerja yang baik agar persepsi masyarakat atas pelayanan publik yang selama ini masih buruk dapat diperbaiki. Dinas Ketahanan Pangan dan Peternakan Provinsi Sumatera Utara merupakan instansi di lingkungan Pemerintah Provinsi Sumatera Utara yang memiliki tugas pokok melaksanakan urusan pemerintahan daerah yang menjadi kewenangan provinsi di bidang ketersediaan dan distribusi pangan, konsumsi dan keamanan pangan, peternakan dan kesehatan hewan. Kinerja pegawai pada instasi tersebut dapat dilihat dari Sasaran Kinerja Pegawai (SKP) dan Perilaku Kinerja Pegawai yang diperoleh pegawai tersebut setiap bulannya. Capaian ini juga yang dijadikan sebagai acuan pembayaran tunjangan tambahan pegawai yang diterima.

\section{LANDASAN TEORI Kinerja}

Salah satu cara yang digunakan untuk melihat perkembangan perusahaan adalah dengan melihat kinerja karyawannya pada perusahaan tersebut. Kinerja merupakan suatu pengukuran hasil dari pekerjaan yang di dalam suatu program yang mewujudkan sasaran berupa hasil atau output yang menjadi hasil suatu evaluasi yang dipertimbangkan oleh manajer untuk mengambil suatu keputusan. Menurut (Pianda, 2018) kinerja adalah sebuah kata dalam Bahasa Indonesia dari kata dasar "kerja" yang menerjemahkan kata dari bahasa asing adalah prestasi, bisa pula berarti hasil kerja. Sedangkan menurut (Rivai, 2014), kinerja merupakan penampilan hasil kerja pegawai baik secara kuantitas maupun mutu. (Noor, 2013) menyatakan bahwa kinerja sebagai sesuatu yang tampak, dimana individu relevan dengan tujuan organisasi. Kinerja yang baik merupakan salah satu sasaran organisasi dalam pencapaian produktivitas kerja yang tinggi. Tercapainya kinerja yang baik tidak terlepas dari kualitas sumber daya manusia yang baik pula. Sedangkan (Mangkuprawira, 2014) mengatakan bahwa kinerja adalah hasil dari proses pekerjaan tertentu secara terencana pada waktu dan tempat dari karyawan serta organisasi bersangkutan. Berbeda dengan (Fahmi, 2017) "Kinerja adalah hasil dari suatu proses yang mengacu dan diukur selama periode waktu tertentu berdasarkan ketentuan atau kesepakatan yang telah ditetapkan sebelumnya."

Definisi kinerja menurut (Torang, 2013) "adalah kuantitas atau kualitas hasil kerja individu atau sekelompok di dalam organisasi dalam melaksanakan tugas pokok dan fungsi yang berpedoman pada norma, standard operasional prosedur, kriteria dan ukuran yang telah ditetapkan atau yang berlaku dalam organisasi. Sedangkan menurut (Sudarmanto, 2011) "kinerja adalah sesuatu yang secara aktual orang kerjakan dan dapat diobservasi. Dalam pengertian ini, kinerja mencakup tindakan-tindakan dan perilaku yang relevan dengan tujuan organisasi. Dari teori-teori yang diketahui di atas maka peneliti mengambil kesimpulan bahwa kinerja adalah suatu proses atau hasil kerja yang dihasilkan oleh pegawai melalui beberapa aspek yang harus dilalui serta memiliki 
tahapan-tahapan untuk mencapainya dan bertujuan untuk meningkatkan kinerja pegawai itu sendiri. Kinerja merupakan elemen yang penting dalam maju mundurnya suatu organisasi, karena kinerja merupakan cerminan bagaimana suatu organisasi itu berjalan ke arah yang benar atau hanya berjalan di tempat saja.

Indikator kinerja merupakan sesuatu yang akan dihitung dan diukur kinerja karyawan secara individu. Menurut (Sutrisno, 2010) mengemukakan secara umum dapat dinyatakan bahwa terdapat 3 aspek indikator kinerja, yaitu sebagai berikut:

1. Kualitas

Kualitas yang dihasilkan, menerangkan tentang jumlah kesalahan, waktu dan ketepatan dalam melakukan tugas.

2. Kuantitas

Kuantitas yang dihasilkan, berkenaan dengan berapa jumlah produk, serta masa kerja yang telah dijalani individu pegawai tersebut.

3. Waktu kerja

Waktu kerja menerangkan akan berapa jumlah absen, keterlambatan, serta masa kerja yang telah dijalani individu pegawa tersebut.

Indikator kinerja menurut (Fattah, 2017) yaitu kuantitas kerja, kualitas kerja, efisiensi dalam melaksanakan tugas, disiplin kerja, inisiatif., ketelitian, kepemimpinan, kejujuran dan kreativitas.

\section{Dukungan Organisasi}

Persepsi dukungan organisasi mengacu pada persepsi karyawan mengenai sejauh mana organisasi menilai kontribusi, memberi dukungan, dan peduli pada kesejahteraan mereka. (Maryati, 2014) mendeskripsikan, Dukungan organisasi adalah kepercayaan pegawai bahwa organisasi peduli dan menilai setiap kontribusinya demi kesuksesan organisasi. Sedangkan menurut (Danish et al., 2013), dukungan organisasi merupakan ekspektasi pegawai bahwa organisasi menghargai kontribusi dan pekerjaan yang pegawai lakukan dengan sebaiknya. Selanjutnya menurut (Erdogan \& Enders, 2007), dukungan oganisasi merupakan derajat kepercayaan individu terhadap organisasi bahwa organisasi peduli kepadanya, menilai setiap masukan yang diberikan, dan menyediakan pertolongan dan bantuan untuknya. (Rhoades \& Eisenberg, 2008) menyatakan bahwa persepsi dukungan organisasi mengacu pada persepsi karyawan mengenai sejauh mana organisasi menilai kontribusi mereka dan peduli pada kesejahteraan mereka. Jika karyawan menganggap bahwa dukungan organisasi yang diterimanya tinggi, maka karyawan tersebut akan menyatukan keanggotaan sebagai anggota organisasi ke dalam identitas diri mereka dan kemudian mengembangkan hubungan dan persepsi yang lebih positif terhadap organisasi tersebut. Menyatunya keanggotaan dalam organisasi dengan identitas diri karyawan, maka karyawan tersebut akan merasa menjadi bagian dari organisasi dan merasa bertanggung jawab untuk berkontribusi dan memberikan performansi terbaiknya pada organisasi/perusahaan.

Menurut (Robbins, 2012), persepsi dukungan organisasi adalah tingkat sampai mana karyawan yakin organisasi menghargai kontribusi mereka dan peduli dengan kesejahteraan mereka. Sedangkan menurut (Wayen, 2011) persepsi dukungan organisasional adalah keyakinan global yang dikembangkan oleh karyawan mengenai sejauh mana komitmen organisasi pada mereka (pegawai) dilihat dari penghargaan organisasi terhadap kontribusi mereka dan perhatian organisasi terhadap kehidupan mereka. Berbeda dengan (Milkovich et al., 2014) yang menyatakan bahwa dukungan organisasi merupakan tanggung jawab organisasi yang menyatakan komitmen organisasi 
terhadap karyawan menyangkut penghargaan atas kinerjanya baik berupa penghargaan langsung atau pengakuan personal.

(Dawley et al., 2010) mendefinisikan dukungan organisasi merupakan tanggapan pembentukan nilai organisasi sebagai kontribusi yang diberikan oleh perusahaan dan kepedulian terhadap kesejahteraan karyawan berdasarkan pada prestasi kerja yang dimiliki oleh karyawan tersebut.

\section{Indikator Dukungan Organisasi}

Indikator dukungan organisasi menurut (Rhoades \& Eisenberg, 2008) adalah sebagai berikut :

1. Penghargaan : perusahaan memberikan penghargaan atau reward atas pencapaian kerja karyawan.

2. Pengembangan : perusahaan memperhatikan kemampuan dan memberikan kesempatan promosi untuk karyawan.

3. Kondisi Kerja : mengenai lingkungan tempat bekerja secara fisik maupun non-fisik.

4. Kesejahteraan karyawan : perusahaan peduli dengan kesejahteraan hidup karyawan.

\section{Lingkungan Kerja}

Lingkungan kerja adalah tempat dimana karyawan melakukan aktivitas setiap harinya. Lingkungan kerja yang kondusif memberikan rasa aman dan memungkinkan karyawan untuk bekerja optimal. Menurut (Siagian, 2014) lingkungan kerja adalah lingkungan dimana pegawai melakukan pekerjaannya sehari-hari. Sedangkan menurut (Robbins, 2012) mengemukakan bahwa lingkungan kerja adalah segala suatu hal atau unsur-unsur yang dapat mempengaruhi secara langsung maupun tidak langsung terhadap organisasi atau perusahaan yang akan memberikan dampak baik atau buruk terhadap kinerja dan kepuasan kerja karyawan.

(Sedarmayanti, 2016) mengatakan bahwa lingkungan kerja non fisik adalah semua keadaan yang terjadi berkaitan dengan hubungan kerja, baik hubungan dengan atasan maupun dengan rekan kerja, ataupun hubungan dengan bawahan. Sedangkan menurut (Nitisemito, 2010), lingkungan kerja adalah segala yang ada di sekitar para pekerja yang dapat mempengaruhi dirinya dalam menjalankan tugas yang dibebankan. Berbeda dengan (Nawawi, 2010) mengartikan bahwa lingkungan kerja adalah kualitas internal operganisasi yang relatif berlangsung terus menerus yang dirasakan oleh anggotanya. (Sofyandi, 2008) mendefinisikan "Lingkungan kerja sebagai serangkaian faktor yang mempengaruhi kinerja dari fungsi-fungsi/ aktivitas-aktivitas manajemen sumber daya manusia yang terdiri dari faktor-faktor internal yang bersumber dari dalam organisasi". (Sunyoto, 2013) mengemukakan "Lingkungan kerja adalah segala sesuatu yang ada di sekitar para pekerja dan yang dapat memengaruhi dirinya dalam menjalankan tugas-tugas yang dibebankan, misalnya kebersihan, musik, penerangan dan lainlain.” Menurut (Basuki \& Susilowati, 2005) lingkungan kerja adalah segala sesuatu yang berada di lingkungan yang dapat mempengaruhi baik secara langsung maupun tidak langsung seseorang atau sekelompok orang di dalam melaksanakan aktivitasnya.

(Mangkunegara, 2014) menjelaskan bahwa lingkungan kerja yang dimaksud antara lain uraian jabatan yang jelas, target kerja yang menantang, pola komunikasi kerja yang efektif, iklim kerja dan fasilitas kerja yang relatif memadai. (Nitisemito, 2010) menyatakan bahwa lingkungan kerja adalah segala sesuatu yang ada disekitar para pekerja dan yang dapat mempengaruhi dirinya dalam menjalankan tugas-tugas yang dibebankan. Dari pendapat para ahli dapat disimpulkan bahwa lingkungan kerja adalah 
segala sesuatu yang ada di sekitar karyawan pada saat bekerja baik berupa fisik maupun non-fisik yang dapat mempengaruhi karyawan saat bekerja. Jika lingkungan kerja yang kondusif maka karyawan bisa aman, nyaman dan jika lingkungan kerja tidak mendukung maka karyawan tidak bisa aman dan nyaman.

Dalam hal menciptakan lingkungan kerja yang nyaman harus memiliki alat ukur indikator untuk lebih mengetahui bagaimana menciptakan lingkungan yang nyaman sesuai dengan keinginan karyawan.

Menurut (Jerry et al., 2012) mengemukakan beberapa indikator yang berkaitan dengan lingkungan kerja, sebagai berikut :

1. Perlengkapan Kerja

Perlengkapan kerja adalah segala sesuatu yang yang berada didalam perusahaan meliputi sarana dan prasarana yang dapat menjadi penunjang pekerjaan. Seperti Komputer, Mesin Ketik, dan lain-lain.

2. Pelayanan Kepada Karyawan

Pelayanan kepada karyawan adalah segala sesuatu yang berkaitan dengan pelayanan perusahaan kepada karyawan, misalnya penyediaan tempat beribadah, sarana kesehatan dan lain-lain.

3. Kondisi Kerja

Kondisi kerja adalah segala sesuatu yang berada di dalam perusahaan dalam bentuk fisik, misalnya seperti ruang, suhu, penerangan, ventilasi udara dan lain lain.

4. Hubungan Personal

Hubungan personal adalah segala sesuatu yang ada di dalam perusahaan berkaitan dengan relasi antar sesama karyawan dari satu karyawan dengan karyawan lainnya, misalnya kerja sama antar karyawan dan atasan.

\section{Kepuasan Kerja}

Kepuasan kerja sebagai hasil keseluruhan dari derajat rasa suka atau tidak sukanya tenaga kerja terhadap berbagai aspek dari pekerjaannya. Menurut (Tiffin \& McCornick, 1997) mengemukakan bahwa kepuasan kerja berhubungan dengan sikap dari karyawan terhadap pekerjaan itu sendiri, situasi kerja, kerjasama antara pimpinan dan sesama karyawan. Sedangkan menurut (Siagian, 2014) kepuasan kerja merupakan suatu cara pandang seseorang baik yang bersifat positif maupun yang bersifat negatif tentang pekerjaannya. (Luthans, 2012) menyebutkan bahwa kepuasan kerja adalah perasaan pekerja atau karyawan yang berhubungan dengan pekerjaannya, yang merasa senang atau tidak senang, sebagai hasil penilaian individu yang bersangkutan terhadap pekerjaannya. Sedangkan menurut (Handoko, 2013) kepuasan kerja adalah keadaan emosional yang menyenangkan atau tidak menyenangkan dimana karyawan memandang pekerjaan mereka. Dari hasil penelitian (Abddurahmat, 2016) mengemukakan bahwa kepuasan kerja merupakan suatu bentuk sikap emosional yang menyenangkan dan mencintai pekerjaan yang digelutinya. Kepuasan kerja dalam pekerjaan ialah kepuasan kerja yang dapat dinikmati dalam pekerjaan dengan mendapatkan hasil dari pencapaian tujuan kerja, penempatan, perlakuan, dan suasana lingkungan kerja yang baik. Karyawan yang dapat menikmati kepuasan kerja dalam pekerjaan ini, akan memilih untuk lebih mengutamakan pekerjaannya daripada balas jasa/upah yang ia dapatkan dari pekerjaan tersebut. Karyawan akan merasa lebih puas apabila balas jasanya sebanding dengan hasil kerja yang dilakukan.

Dalam penelitian (Richard, 2012) menegaskan bahwa kepuasan kerja berhubungan dengan perasaan atau sikap seseorang mengenai pekerjaan itu sendiri, gaji, 
kesempatan promosi atau pendidikan, pengawasan, rekan kerja, beban kerja dan lain-lain. Dalam hal ini, yang dimaksud dengan sikap tersebut adalah segala hal yang berhubungan dengan pekerjaan seperti pengawasan supervisi, gaji, kondisi kerja, pengalaman terhadap kecakapan, penilaian kerja yang adil dan tidak merugikan, hubungan sosial di dalam pekerjaan yang baik, penyelesaian yang cepat terhadap keluhan dan perlakuan yang baik dari pimpinan terhadap pegawai. (Mathis \& Jackson, 2002) menyebutkan bahwa kepuasan kerja adalah keadaan emosional yang positif yang merupakan hasil dari evaluasi pengalaman kerja seseorang. Sedangkan (Wagner \& Hollenbeck, 2010) mengemukakan bahwa kepuasan kerja adalah perasaan senang atau pernyataan emosi yang positif dari hasil pemenuhan suatu pekerjaan atau pengalaman-pengalaman pekerjaan. Berbeda dengan (Bangun, 2012) menyatakan bahwa dengan kepuasan kerja seorang pegawai dapat merasakan pekerjaannya apakah menyenangkan atau tidak menyenangkan untuk dikerjakan. Dari pernyataan beberapa ahli di atas mengenai pengertian kepuasan kerja, peneliti dapat menyimpulkan bahwa kepuasan kerja merupakan sikap positif yang ditunjukkan oleh karyawan terhadap pekerjaannya, sehingga karyawan dapat bekerja dengan senang hati tanpa merasa terbebani dengan pekerjaan tersebut dan memberikan hasil yang optimal bagi perusahaan.

\section{Indikator Kepuasan Kerja}

Kepuasan kerja adalah sebagai suatu sikap umum seseorang individu terhadap pekerjaannya. Menurut (Rivai, 2014) indikator dari kepuasan kerja terdiri dari:

1. Isi pekerjaan

Penampilan tugas atau atribut pekerjaan yang aktual dan sebagai kontrol terhadap pekerjaan. Karyawan akan merasa puas apabila tugas kerja dianggap menarik dan memberikan kesempatan belajar dan mendapat kepercayaan tanggung jawab atas pekerjaan itu.

2. Supervisi

Perhatian dan hubungan yang baik dari pimpinan kepada bawahan, sehingga karyawan akan merasa bahwa dirinya menjadi bagian yang penting dari organisasi. Sebaliknya, supervisi yang buruk dapat meningkatkan turnover dan absensi karyawan.

3. Organisasi dan manajemen

Perusahaan dan manajemen yang baik adalah yang mampu memberikan situasi dan kondisi kerja yang stabil, untuk memberikan kepuasan kepada karyawan.

4. Kesempatan untuk maju

Adanya kesempatan untuk memperoleh pengalaman dan peningkatan kemampuan selama bekerja akan memberikan kepuasan pada karyawan terhadap pekerjaannya.

5. Gaji dan keuntungan dalam bidang finansial

Gaji adalah suatu jumlah yang diterima dan keadaan yang dirasakan dari upah (gaji). Jika karyawan merasa bahwa gaji yang diperoleh mampu memenuhi kebutuhan hidupnya, diberikan secara adil didasarkan pada tingkat keterampilannya, tuntutan pekerjaan, serta standar gaji untuk pekerjaan tertentu, maka akan ada kepuasan kerja.

6. Rekan Kerja

Adanya hubungan yang dirasa saling mendukung dan saling memperhatikan antar rekan akan menciptakan lingkungan kerja yang nyaman dan hangat sehingga menimbulkan kepuasan kerja pada karyawan.

7. Kondisi Kerja 
Kondisi kerja yang mendukung akan meningkatkan kepuasan kerja pada karyawan. Kondisi kerja yang mendukung artinya tersedianya sarana dan prasarana kerja yang memadai sesuai dengan sifat tugas yang harus diselesaikannya.

\section{Hubungan Dukungan Organisasi Terhadap Kinerja}

Dukungan organisasi yang dirasakan karyawan mencerminkan perasaan terdalamnya tentang perhatian dan penekanan organisasi. Karyawan dengan rasa dukungan organisasi merasa bahwa dalam situasi dimana mereka membutuhkan dukungan kerja atau kehidupan, organisasi bersedia membantu; karyawan secara pribadi merasa dihormati, diperhatikan, dan diakui, dan pada gilirannya menunjukkan peningkatan kerjasama, identifikasi, kinerja yang rajin penghargaan, dan timbal balik di antara para pekerja (Defrionaldo \& Rivai, 2019).

Hipotesis : Dukungan organisasi berpengaruh terhadap kinerja karyawan.

\section{Hubungan Lingkungan kerja terhadap Kinerja Pegawai}

Lingkungan kerja adalah: "segala sesuatu yang ada disekitar para pekerja yang dapat memengaruhi dirinya dalam menjalankan tugas-tugas yang dibebankan, misalnya kebersihan, musik, penerangan, dan lain-lain" (Sunyoto, 2013) Jika dalam penciptaan suasana yang menarik terhadap pandangan pegawai atas pekerjaannya, instansi perlu memperhatikan faktor kondisi kerja. Beberapa faktor perlu diperhatikan dalam kaitannya dengan kondisi kerja antara lain, tersedianya fasilitas yang memadai, ruang kerja yang bersih dan kantor yang bergengsi. Kebijakan organisasional bukan hanya bermanfaat pada satu pihak, instansi akan mendapatkan suatu sistem dalam mengelola pegawai secara berkesinambungan, walaupun awalnya mengeluarkan dana relatif besar. Pada pihak lain, para pegawai akan memperoleh hasil dalam pengembangan dirinya, sehingga dapat meningkatkan prestasi kerjanya yang pada akhirnya berpengaruh pada peningkatan kinerja instansi juga (Sinambela \& Tanjung, 2018)

Hipotesis : lingkungan kerja berpengaruh terhadap kinerja

\section{Hubungan Dukungan Organisasi Terhadap Kepuasan Kerja}

Dukungan organisasional yang diukur dengan keadilan, dukungan atasan dan penghargaan organisasi \& kondisi pekerjaan telah dikelola dengan baik oleh vendor sehingga memberikan kontribusi terhadap kepuasan kerja karyawan. Menurut penilaian karyawan komunikasi yang terbuka dan tersedianya pelatihan menjadi faktor peningkatan kepuasan kerja (Putra et al., 2016)

Hipotesis : Dukungan organisasi berpengaruh terdahap kepuasan kerja

\section{Hubungan Lingkungan Kerja Terhadap Kepuasan Kerja}

Lingkungan kerja non-fisik berperan penting untuk meningkatkan kepuasan kerja karyawan. Hal ini terjadi karena lingkungan kerja non-fisik seperti struktur tugas, desain pekerjaan, pola kepemimpinan, pola kerja sama dan budaya organisasi semakin baik, maka kepuasan kerja karyawan pun juga semakin membaik (Wibowo et al., 2014).

Hipotesis : lingkungan kerja berpengaruh terdahap kepuasan kerja.

\section{Hubungan Dukungan Organisasi Terhadap Kinerja Pegawai Melalui Kepuasan Kerja}

Dukungan organisasional yang dirasakan merupakan sumber daya penting yang diperhatikan dalam pengelolaan lingkungan kerja terutama di sektor jasa. Karyawan yang 
merasakan dukungan organisasi akan bisa bekerja dengan baik karena fasilitas serta kontribusi perusahaan yang membuat karyawan merasa nyaman dan aman memicu semangat kerja karyawan bertambah dan membuat karyawan bertahan pada perusahaan tersebut dalam jangka waktu yang lama. Hal ini menunjukkan bahwa semakin tinggi dukungan organisasi yang terjadi di perusahaan maka semakin tinggi juga kepuasan kerja pada karyawan sehingga karyawan akan terus giat dalam mengerjakan pekerjaanya dan pada akhirnya kienrja karyawan tersebut akan semakin meningkat.

Hipotesis : Dukungan organisasi berpengaruh terhadap kinerja karyawan dan dukungan organisasi berpengaruh terdahap kepuasan kerja

\section{METODOLOGI PENELITIAN}

Penelitian dilaksanakan mulai bulan Maret 2021 sampai dengan Agustus 2021 Dalam penelitian ini menggunakan jenis pendekatan assosiatif dan kuantitatif. Pendekatan assosiatif adalah suatu pendekatan dimana untuk mengetahui bahwa adanya hubungan pengaruh atau pengaruh diantara kedua variabel yaitu variabel bebas (independent variable) dan variabel terikat (dependent variable). Kemudian data yang dikumpulkan dalam bentuk kuantitatif. Populasi dalam penelitian ini adalah seluruh pegawai aparatur sipil Negara yang bertugas pada kantor Dinas Ketahanan Pangan dan Peternakan Provinsi Sumatera Utara sejumlah 210 orang. jumlah sampel dalam penelitian ini adalah sebanyak 68 orang pegawai Dinas Ketahanan Pangan dan Peternakan Provinsi Sumatera Utara, Pengambilan sampel ini menggunakan metode probability sampling. Data ini akan dianalisis dengan pendekatan kuantitatif menggunakan analisis statistik yakni partial least square - structural equestion model (PLSSEM) yang bertujuan untuk melakukan analisis jalur (path) dengan variabel laten. Analisis ini sering disebut sebagai generasi kedua dari analisis multivariate (Ghozali \& Latari, 2015).

\section{HASIL PENELITIAN DAN PEMBAHASAN ANALISIS DATA}

Tabel 1 Hasil AVE (Average Variant Extracted)

\begin{tabular}{|c|r|c|}
\hline Variabel / Konstruk & \multicolumn{1}{c|}{ AVE } & Hasil Uji \\
\hline Dukungan Organisasi (X1) & 0649 & Valid \\
\hline Lingkungan kerja (X2) & 0.659 & Valid \\
\hline Kepuasan Kerja (Z) & 0.553 & Valid \\
\hline Kinerja (Y) & 0.624 & Valid \\
\hline
\end{tabular}

(Sumber : Data Diolah, 2020)

Berdasarkan tabel di atas diketahui bahwa nilai AVE setiap variabel adalah lebih besar dari 0,5. Sehingga dapat disimpulkan bahwa variabel atau konstruk yang digunakan adalah valid.

Tabel 2 Hasil Cross Loading

\begin{tabular}{|l|l|c|c|c|c|c|}
\hline No. & \multicolumn{1}{|c|}{ Butir Pernyataan } & X1 & X2 & Z & Y & $\begin{array}{c}\text { Hasil } \\
\text { Uji }\end{array}$ \\
\hline Dukungan Organisasi (X1) & 0.737 & 0.586 & 0.625 & 0.654 & Valid \\
\hline 1. & $\mathrm{X} 1.1$ & 0.760 & 0.527 & 0.512 & 0.604 & Valid \\
\hline 2. & $\mathrm{X} 1.2$ & 0.775 & 0.525 & 0.551 & 0.708 & Valid \\
\hline 3. & $\mathrm{X} 1.3$ & 0.727 & 0.649 & 0.704 & 0.700 & Valid \\
\hline 4. & $\mathrm{X} 1.4$ & 0.920 & 0.817 & 0.776 & 0.808 & Valid \\
\hline 5. & $\mathrm{X} 1.5$ & & & & & \\
\hline
\end{tabular}




\begin{tabular}{|l|l|c|c|c|c|c|}
\hline No. & \multicolumn{1}{|c|}{ Butir Pernyataan } & X1 & X2 & Z & Y & $\begin{array}{c}\text { Hasil } \\
\text { Uji }\end{array}$ \\
\hline 6. & X1.6 & 0.895 & 0.680 & 0.639 & 0.745 & Valid \\
\hline $\begin{array}{l}\text { Lingkungan Kerja (X2) } \\
1 .\end{array}$ X2.1 & 0.628 & 0.826 & 0.768 & 0.675 & Valid \\
\hline 2. & X2.2 & 0.648 & 0.871 & 0.767 & 0.695 & Valid \\
\hline 3. & X2.3 & 0.594 & 0.674 & 0.522 & 0.520 & Valid \\
\hline 4. & X2.4 & 0.719 & 0.848 & 0.779 & 0.779 & Valid \\
\hline 5. & X2.5 & 0.651 & 0.821 & 0.673 & 0.645 & Valid \\
\hline 6. & X2.6 & 0.626 & 0.816 & 0.778 & 0.688 & Valid \\
\hline Kepuasan Kerja(Z) & 0.626 & 0.816 & 0.778 & 0.688 & Valid \\
\hline 1. & Z1.1 & 0.460 & 0.654 & 0.660 & 0.519 & Valid \\
\hline 2. & Z1.2 & 0.729 & 0.764 & 0.872 & 0.857 & Valid \\
\hline 3. & Z1.3 & 0.609 & 0.620 & 0.800 & 0.790 & Valid \\
\hline 4. & Z1.4 & 0.678 & 0.764 & 0.855 & 0.837 & Valid \\
\hline 5. & Z1.5 & 0.702 & 0.666 & 0.830 & 0.812 & Valid \\
\hline 6 & Z1.6 & - & - & 0.083 & 0.098 & Valid \\
\hline 7 & Z1.7 & 0.022 & 0.049 & 0.083 & \\
\hline Kinerja (Y) & \multicolumn{5}{|l|}{} \\
\hline 1. & Y1.1 & 0.702 & 0.666 & 0.830 & 0.812 & Valid \\
\hline 2. & Y1.2 & 0.782 & 0.566 & 0.559 & 0.708 & Valid \\
\hline 3. & Y1.3 & 0.729 & 0.764 & 0.872 & 0.857 & Valid \\
\hline 4. & Y1.4 & 0.609 & 0.620 & 0.800 & 0.790 & Valid \\
\hline 5. & Y1.5 & 0.678 & 0.762 & 0.855 & 0.837 & Valid \\
\hline 6. & Y1.6 & 0.560 & 0.709 & 0.710 & 0.726 & Valid \\
\hline 7. & Y1.7 & 0.754 & 0.616 & 0.702 & 0.822 & Valid \\
\hline 8. & Y1.8 & 0.762 & 0.511 & 0.591 & 0.755 & Valid \\
\hline
\end{tabular}

(Sumber : Data Diolah, 2021)

Berdasarkan sajian data pada tabel 2 di atas dapat diketahui bahwa masing-masing indikator pada variabel penelitian memiliki nilai cross loading lebih tinggi pada variabel yang dibentuknya dibandingkan dengan nilai cross loading pada variabel lainnya. Berdasarkan hasil yang diperoleh tersebut, dapat dinyatakan bahwa indikator-indikator yang digunakan dalam penelitian ini telah memiliki discriminant validity yang baik dalam menyusun variabelnya masing-masing.

Tabel 3 Hasil Uji Reabilitas

\begin{tabular}{|c|c|r|l|}
\hline Variabel / Konstruk & $\begin{array}{c}\text { Cronbach's } \\
\text { Alpha }\end{array}$ & $\begin{array}{c}\text { Composite } \\
\text { Reliability }\end{array}$ & Hasil Uji \\
\hline Dukungan Organisasi (X1) & $\mathbf{0 . 8 9 0}$ & 0,60 & Reliabel \\
\hline Lingkungan kerja (X2) & $\mathbf{0 . 8 9 5}$ & 0,60 & Reliabel \\
\hline Kepuasan Kerja (Z) & $\mathbf{0 . 9 1 3}$ & 0,60 & Reliabel \\
\hline Kinerja (Y) & $\mathbf{0 . 8 3 7}$ & 0,60 & Reliabel \\
\hline
\end{tabular}

(Sumber : Data Diolah, 2021) 
Berdasarkan sajian data pada tabel 4.15 di atas dapat diketahui bahwa masingmasing variabel penelitian memiliki nilai cronbach's alpha dan composite reliability> 0,60. Berdasarkan hasil yang diperoleh tersebut, dapat dinyatakan bahwa variabel yang digunakan dalam penelitian dinyatakan reliabel.

Tabel 4 Nilai $F$-Square

\begin{tabular}{|c|c|}
\hline Variabel & F-Square \\
\hline \hline Dukungan Organisasi $\rightarrow$ Kinerja & 0,598 \\
\hline Lingkungan Kerja $\rightarrow$ Kinerja & 0,354 \\
\hline Kepuasan Kerja $\rightarrow$ Kinerja & 0,825 \\
\hline Dukungan Organisasi $\rightarrow$ Kepuasan Kerja & 0,247 \\
\hline Lingkungan Kerja $\rightarrow$ Kepuasan Kerja & 0,693 \\
\hline Dukungan Organisasi $\rightarrow$ Kinerja dimediasi oleh Kepuasan Kerja & 0,204 \\
\hline Lingkungan Kerja $\rightarrow$ Kinerja dimediasi oleh Kepuasan Kerja & 0,572 \\
\hline
\end{tabular}

Sumber : PLS 3.00

Berdasarkan tabel 4 di atas diketahui bahwa :

1. Pengaruh Dukungan organisasi (X1) terhadap kinerja (Y) memiliki nilai $\mathrm{F}^{2}$ sebesar 0,598 mengindikasikan bahwa terdapat efek yang besar (baik).

2. Pengaruh lingkungan kerja (X2) terhadap kinerja (Y) memiliki nilai $\mathrm{F}^{2}$ sebesar 0,354 mengindikasikan bahwa terdapat efek yang besar (baik).

3. Pengaruh kepuasan kerja $(\mathrm{Z})$ terhadap kinerja $(\mathrm{Y})$ memiliki nilai $\mathrm{F}^{2}$ sebesar 0,825 mengindikasikan bahwa terdapat efek yang besar (baik).

4. Pengaruh dukungan organisasi (X1) terhadap kepuasan kerja (Z) memiliki nilai $\mathrm{F}^{2}$ sebesar 0,247 mengindikasikan bahwa terdapat efek yang moderat (sedang).

5. Pengaruh lingkungan kerja (X2) terhadap kepuasan kerja (Z) memiliki nilai $\mathrm{F}^{2}$ sebesar 0,693 mengindikasikan bahwa terdapat efek yang besar (baik).

6. Pengaruh dukungan organisasi (X1) terhadap kinerja (Y) dimediasi oleh kepuasan kerja (Z) memiliki nilai $\mathrm{F}^{2}$ sebesar 0,204mengindikasikan bahwa terdapat efek yang moderat (sedang).

7. Pengaruh lingkungan kerja (X2) terhadap kinerja (Y) dimediasi oleh kepuasan kerja (Z) memiliki nilai $\mathrm{F}^{2}$ sebesar 0,572 mengindikasikan bahwa terdapat efek yang besar (baik).

Tabel 5 Hasil Uji R-Square

\begin{tabular}{|l|ll|l|}
\hline & R Square & R Square Adjusted & \\
\hline $\mathbf{Y}$ & & 0.946 & 0.943 \\
\hline
\end{tabular}

Sumber : PLS 3.00

Dari tabel 5 di atas diketahui bahwa pengaruh X1, X2 dan Z terhadap Y dengan nilai r-square 0,946 mengindikasikan bahwa variasi nilai Y mampu dijelaskan oleh variasi nilai X1, X2 dan Z sebesar 94,6\% atau dengan kata lain bahwa model tersebut adalah substansial (baik), dan 5,6\% dipengaruhi oleh variabel lain.

\section{PENGUJIAN HIPOTESIS}

Tabel 6 Path Coefficient

\begin{tabular}{|l|c|c|c|c|c|}
\hline & $\begin{array}{c}\text { Original } \\
\text { Sample } \\
(\mathbf{O})\end{array}$ & $\begin{array}{c}\text { Sample } \\
\text { Mean } \\
(\mathbf{M})\end{array}$ & $\begin{array}{c}\text { Standard } \\
\text { Error } \\
(\text { STERR })\end{array}$ & $\begin{array}{c}\text { T Statistics } \\
(\text { |O/STERR })\end{array}$ & $\begin{array}{c}\text { P } \\
\text { Values }\end{array}$ \\
\hline \hline Dukungan Organisasi $\rightarrow$ Kinerja & 0,395 & 0,391 & 0,062 & 6,400 & $\mathbf{0 . 0 0 0}$ \\
\hline
\end{tabular}




\begin{tabular}{|l|r|r|r|r|r|}
\hline $\begin{array}{l}\text { Dukungan Organisasi } \rightarrow \text { Kepuasan } \\
\text { Kerja }\end{array}$ & 0,247 & 0,277 & 0,107 & 2,314 & $\mathbf{0 . 0 2 1}$ \\
\hline Lingkungan Kerja $\rightarrow$ Kinerja & 0,218 & 0,207 & 0,074 & 2,965 & $\mathbf{0 . 0 0 3}$ \\
\hline Lingkungan Kerja $\rightarrow$ Kepuasan Kerja & 0,693 & 0,659 & 0,110 & 6,280 & $\mathbf{0 . 0 0 0}$ \\
\hline Kepuasan Kerja $\rightarrow$ Kinerja & 0,825 & 0,815 & 0,076 & 10,886 & $\mathbf{0 . 0 0 0}$ \\
\hline
\end{tabular}

Sumber : PLS 3.00

Berdasarkan Tabel 6, dapat dinyatakan bahwa pengujian hipotesis adalah sebagai berikut :

1. Pengaruh dukungan organisasi terhadap kinerja mempunyai koefisien jalur sebesar 0,395 . Pengaruh tersebut mempunyai nilai probabilitas ( $p$-values) sebesar $0,000<0,05$, berarti dukungan organisasi berpengaruh signifikan terhadap kinerja pegawai pada Dinas Ketahanan Pangan dan Peternakan Provinsi Sumatera Utara.

2. Pengaruh dukungan organisasi terhadap kepuasan kerja mempunyai koefisien jalur sebesar 0,247. Pengaruh tersebut mempunyai nilai probabilitas ( $\mathrm{p}$-values) sebesar $0,021<0,05$, berarti dukungan organisasi berpengaruh signifikan terhadap kepuasan kerja pegawai pada Dinas Ketahanan Pangan dan Peternakan Provinsi Sumatera Utara.

3. Pengaruh lingkungan kerja terhadap kinerja mempunyai koefisien jalur sebesar 0,218 . Pengaruh tersebut mempunyai nilai probabilitas (p-values) sebesar $0,003<0,05$, berarti lingkungan kerja berpengaruh signifikan terhadap kinerja pegawai pada Dinas Ketahanan Pangan dan Peternakan Provinsi Sumatera Utara.

4. Pengaruh lingkungan kerja terhadap kepuasan kerja mempunyai koefisien jalur sebesar 0,693. Pengaruh tersebut mempunyai nilai probabilitas ( $p$-values) sebesar $0,000<0,05$, berarti lingkungan kerja berpengaruh signifikan terhadap kepuasan kerja pegawai pada Dinas Ketahanan Pangan dan Peternakan Provinsi Sumatera Utara.

5. Pengaruh kepuasan kerja terhadap kinerja mempunyai koefisien jalur sebesar 0,825 . Pengaruh tersebut mempunyai nilai probabilitas ( $\mathrm{p}$-values) sebesar $0,000<0,05$, berarti kepuasan kerja berpengaruh signifikan terhadap kinerja pegawai pada kantor Dinas Ketahanan Pangan dan Peternakan Provinsi Sumatera Utara.

Tabel 7 Specific Indirect Effects

\begin{tabular}{|l|c|c|r|l|c|}
\hline & $\begin{array}{c}\text { Original } \\
\text { Sample } \\
(\mathbf{O})\end{array}$ & $\begin{array}{c}\text { Sample } \\
\text { Mean } \\
(\mathbf{M})\end{array}$ & $\begin{array}{c}\text { Standard } \\
\text { Deviation } \\
(\text { STDEV) }\end{array}$ & $\begin{array}{l}\text { T Statistics } \\
(\mid \mathbf{O} / \mathbf{S T D E V})\end{array}$ & \multicolumn{1}{c|}{ P } \\
Values \\
\hline $\begin{array}{l}\text { Dukungan Organisasi } \rightarrow \text { Kepuasan } \\
\text { Kerja } \rightarrow \text { Kinerja }\end{array}$ & 0.204 & 0.226 & 0.090 & 2,277 & $\mathbf{0 . 0 2 3}$ \\
\hline $\begin{array}{l}\text { Lingkungan Kerja } \rightarrow \text { Kepuasan Kerja } \\
\rightarrow \text { Kinerja }\end{array}$ & 0.572 & 0.536 & 0.101 & 5,636 & $\mathbf{0 . 0 0 0}$ \\
\hline
\end{tabular}

Sumber : PLS 3.00

Berdasarkan Tabel 7 di atas, dapat dinyatakan bahwa pengujian hipotesis adalah sebagai berikut :

1. Pengaruh dukungan organisasi terhadap kinerja dimediasi kepuasan kerja mempunyai koefisien jalur sebesar 0,204 . Pengaruh tersebut mempunyai nilai probabilitas ( $\mathrm{p}$ values) sebesar $0,023<0,05$, berarti dapat disimpulkan bahwa dukungan organisasi berpengaruh signifikan terhadap kinerja pegawai dimediasi oleh kepuasan kerja pegawai pada Dinas Ketahanan Pangan dan Peternakan Provinsi Sumatera Utara.

2. Pengaruh lingkungan kerja terhadap kinerja dimediasi oleh kepuasan kerja mempunyai koefisien jalur sebesar 0,572. Pengaruh tersebut mempunyai nilai probabilitas (pvalues) sebesar $0,000<0,05$, berarti dapat disimpulkan bahwa kepuasan kerja berpengaruh signifikan terhadap kinerja pegawai dimediasi kepuasan kerja pegawai pada Dinas Ketahanan Pangan dan Peternakan Provinsi Sumatera Utara. 


\section{PEMBAHASAN}

\section{Pengaruh Dukungan Organisasi Terhadap Kinerja}

Dari hasil analisis pengujian hipotesis diketahui bahwa dukungan organisasi berpengaruh signifikan terhadap kinerja yang dinilai dengan koefisien jalur sebesar 0,395 . Nilai probabilitas yang didapatkan adalah sebesar $0,000<0,05$, dengan nilai thitung sebesar 6,400, dan nilai $t_{\text {tabel }} 1.96$, dengan demikian $t_{\text {hitung }}$ lebih besar dari $t_{\text {tabel }}$ $(6,400>1.96)$ sehingga H0 ditolak (Ha diterima). Hal ini berarti dukungan organisasi berpengaruh signifikan terhadap kinerja pegawai pada Dinas Ketahanan Pangan dan Peternakan Provinsi Sumatera Utara.

Dukungan organisasi yang dirasakan karyawan mencerminkan perasaan terdalamnya tentang perhatian dan penekanan organisasi. Karyawan dengan rasa dukungan organisasi merasa bahwa dalam situasi dimana mereka membutuhkan dukungan kerja atau kehidupan, organisasi bersedia membantu; karyawan secara pribadi merasa dihormati, diperhatikan dan diakui, dan pada gilirannya menunjukkan peningkatan kerjasama, identifikasi, kinerja yang rajin penghargaan, dan timbal balik di antara para pekerja (Defrionaldo \& Rivai, 2019). Hasil penelitian ini sejalan dengan hasil penelitian terdahulu yang dilakukan oleh (Riantoko et al., 2017), (Defrionaldo \& Rivai, 2019), (Muis et al., 2018) menyimpulkan bahwa dukungan organisasi berpengaruh terhadap kinerja karyawan.

\section{Pengaruh Lingkungan Kerja Terhadap Kinerja}

Dari hasil analisis pengujian hipotesis diketahui bahwa lingkungan kerja berpengaruh signifikan terhadap kinerja yang dinilai dengan koefisien jalur sebesar 0,218 . Nilai probabilitas yang didapatkan adalah sebesar $0,003<0,05$, dengan nilai thitung sebesar 2,96, dan nilai tabel 1.96, dengan demikian $t_{\text {hitung }}$ lebih besar dari $t_{\text {tabel }}$ (2,965>1.96) sehingga $\mathrm{HO}$ ditolak (Ha diterima). Hal ini berarti lingkungan kerja berpengaruh signifikan terhadap kinerja pegawai pada Dinas Ketahanan Pangan dan Peternakan Provinsi Sumatera Utara.

Jika dalam penciptaan suasana yang menarik terhadap pandangan pegawai atas pekerjaannya, instansi perlu memperhatikan faktor kondisi kerja. Beberapa faktor perlu diperhatikan dalam kaitannya dengan kondisi kerja antara lain, tersedianya fasilitas yang memadai, ruang kerja yang bersih dan kantor yang bergengsi. Kebijakan organisasional bukan hanya bermanfaat pada satu pihak, instansi akan mendapatkan suatu sistem dalam mengelola pegawai secara berkesinambungan, walaupun awalnya mengeluarkan dana relatif besar. Pada pihak lain, para pegawai akan memperoleh hasil dalam pengembangan dirinya, sehingga dapat meningkatkan prestasi kerjanya yang pada akhirnya berpengaruh pada peningkatan kinerja instansi juga (Sinambela \& Tanjung, 2018). Lingkungan kerja adalah: "segala sesuatu yang ada disekitar para pekerja yang dapat memengaruhi dirinya dalam menjalankan tugas-tugas yang dibebankan, misalnya kebersihan, musik, penerangan, dan lain-lain" (Sunyoto, 2013). Hasil penelitian ini sejalan dengan hasil penelitan terdahulu yang dilakukan oleh (Sinambela \& Tanjung, 2018), (Farisi \& Fani, 2019), (Puspita, 2011), (Jufrizen \& Rahmadhani, 2020) (Bahagia et al., 2018) menyimpulkan bahwa lingkungan kerja berpengaruh terhadap kinerja.

\section{Pengaruh Kepuasan Kerja Terhadap Kinerja}

Dari hasil analisis pengujian hipotesis diketahui bahwa kepuasan kerja berpengaruh signifikan terhadap kinerja yang dinilai dengan koefisien jalur sebesar 0,825 . Nilai probabilitas yang didapatkan adalah sebesar $0,000<0,05$, dengan nilai thitung 
sebesar 10,886, dan nilai tabel 1.96, dengan demikian $t_{\text {hitung }}$ lebih besar dari $t_{\text {tabel }}$ (10,886>1.96) sehingga H0 ditolak (Ha diterima). Hal ini berarti kepuasan kerja berpengaruh signifikan terhadap kinerja pegawai pada Dinas Ketahanan Pangan dan Peternakan Provinsi Sumatera Utara.Kepuasan kerja dalam suatu perusahaan sangat dibutuhkan untuk mendongkrak kinerja karyawan. Kepuasan kerja dapat diperoleh berupa gaji pokok, kompensasi, peluang kenaikan gaji, peluang promosi jabatan, penghargaan, perjalanan ke luar negeri, hubungan kerja (Wijaya, 2018).

Kepuasan kerja karyawan merupakan masalah penting yang diperhatikan dalam hubungannya dengan produktivitas kerja karyawan dan ketidakpuasan sering dikaitkan dengan tingkat tuntutan dan keluhan pekerjaan yang tinggi. Pekerja dengan tingkat ketidakpuasan yang tinggi lebih mungkin untuk melakukan sabotase dan agresi yang pasif (Sutrisno, 2010). Hasil penelitian ini sejalan dengan hasil penelitian terdahulu yang dilakuan oleh (Wijaya, 2018), (Saputra et al., 2016), (Jufrizen, 2017), (Syahputra \& Jufrizen, 2019), (Jufrizen et al., 2017) dan (Adhan et al., 2020) menyimpulkan bahwa kepuasan kerja berpengaruh terhadap kinerja.

\section{Pengaruh Dukungan Organisasi Terhadap Kepuasan Kerja}

Dari hasil analisis pengujian hipotesis diketahui bahwa dukungan organisasi berpengaruh signifikan terhadap kepuasan kerja yang dinilai dengan koefisien jalur sebesar 0,247. Nilai probabilitas yang didapatkan adalah sebesar 0,021<0,05, dengan nilai thitung sebesar 2,316, dan nilai tabel 1.96, dengan demikian $t_{\text {hitung }}$ lebih besar dari $t_{\text {tabel }}(2,316>1.96)$ sehingga $\mathrm{HO}$ ditolak (Ha diterima). Hal ini berarti dukungan organisasi berpengaruh signifikan terhadap kepuasan kerja pada Dinas Ketahanan Pangan dan Peternakan Provinsi Sumatera Utara. Dukungan organisasi mengusulkan bahwa pegawai membentuk persepsi umum mengenai sejauh mana organisasi menyediakan sumber daya yang memadai dan menghargai mereka sebagai individu, termasuk kemungkinan bahwa organisasi akan menghargai kinerja mereka dan membantu mereka selama mengalami kesulitan.

Dukungan organisasional yang diukur dengan keadilan, dukungan atasan dan penghargaan organisasi \& kondisi pekerjaan telah dikelola dengan baik oleh vendor sehingga memberikan kontribusi terhadap kepuasan kerja karyawan. Menurut penilaian karyawan komunikasi yang terbuka dan tersedianya pelatihan menjadi faktor peningkatan kepuasan kerja (Putra et al., 2016). Hasil penelitian ini sejalan dengan hasil penelitian terdahulu yang dilaukan oleh (Putra et al., 2016) menyimpulkan bahwa dukungan organisasi berpengaruh terdahap kepuasan kerja.

\section{Pengaruh Lingkungan Kerja Terhadap Kepuasan Kerja}

Dari hasil analisis pengujian hipotesis diketahui bahwa lingkungan kerja berpengaruh signifikan terhadap kepuasan kerja yang dinilai dengan koefisien jalur sebesar 0,693. Nilai probabilitas yang didapatkan adalah sebesar $0,000<0,05$, dengan nilai thitung sebesar 6,280 , dan nilai $t_{\text {tabel }} 1.96$, dengan demikian $t_{\text {hitung }}$ lebih besar dari $t_{\text {tabel }}(6,280>1.96)$ sehingga H0 ditolak (Ha diterima). Hal ini berarti lingkungan kerja berpengaruh signifikan terhadap kepuasan kerja pada Dinas Ketahanan Pangan dan Peternakan Provinsi Sumatera Utara.

Lingkungan kerja non-fisik berperan penting untuk meningkatkan kepuasan kerja karyawan. Hal ini terjadi karena lingkungan kerja non-fisik seperti struktur tugas, desain pekerjaan, pola kepemimpinan, pola kerja sama dan budaya organisasi semakin baik, maka kepuasan kerja karyawan pun juga semakin membaik (Wibowo et al., 2014) 
Hasil penelitian ini sejalan dengan hasil penelitian terdahulu yang dilakukan oleh (Aruan \& Fakhri, 2015), (Wibowo et al., 2014), (Rasyid \& Tanjung, 2020), (Astuti \& Iverizkinawati, 2018) menyimpulkan bahwa lingkungan kerja berpengaruh terdahap kepuasan kerja.

\section{Pengaruh Dukungan Organisasi Terhadap Kinerja Dimediasi Oleh Kepuasan Kerja}

Dari hasil analisis pengujian hipotesis diketahui bahwa dukungan organisasi berpengaruh signifikan terhadap kinerja dimediasi oleh kepuasan kerja yang dinilai dengan koefisien jalur sebesar 0,204. Nilai probabilitas yang didapatkan adalah sebesar $0,023<0,05$, dengan nilai $t_{\text {hitung }}$ sebesar 2,277 , dan nilai $t_{\text {tabel }} 1.96$, dengan demikian $t_{\text {hitung }}$ lebih besar dari $t_{\text {tabel }}(2,277>1.96)$ sehingga $\mathrm{HO}$ ditolak (Ha diterima). Hal ini berarti dukungan organisasi berpengaruh signifikan terhadap kinerja dimediasi oleh kepuasan kerja pada Dinas Ketahanan Pangan dan Peternakan Provinsi Sumatera Utara. Pegawai yang merasakan dukungan organisasi akan bisa bekerja dengan baik karena fasilitas serta kontribusi perusahaan yang membuat pegawai merasa nyaman dan aman memicu semangat kerja pegawai bertambah dan membuat pegawai bertahan pada perusahaan tersebut dalam jangka waktu yang lama. Hal ini menunjukkan bahwa semakin tinggi dukungan organisasi yang terjadi di perusahaan maka semakin tinggi juga kepuasan kerja pada karyawan sehingga pegawai akan terus giat dalam mengerjakan pekerjaanya dan pada akhirnya kinerja pegawai tersebut akan semakin meningkat.

Berdasarkan penelitian terdahulu yang dilakukan oleh (Riantoko et al., 2017), (Defrionaldo \& Rivai, 2019), Muis et al., 2018) menyimpulkan bahwa dukungan organisasi berpengaruh terhadap kinerja karyawan.

\section{Pengaruh Lingkungan Kerja Terhadap Kinerja Dimediasi Oleh Kepuasan Kerja}

Dari hasil analisis pengujian hipotesis diketahui bahwa lingkungan kerja berpengaruh signifikan terhadap kinerja dimediasi oleh kepuasan kerja yang dinilai dengan koefisien jalur sebesar 0,572 . Nilai probabilitas yang didapatkan adalah sebesar $0,000<0,05$, dengan nilai thitung sebesar 5,636, dan nilai tabel 1.96, dengan demikian $t_{\text {hitung }}$ lebih besar dari $t_{\text {tabel }}(5,636>1.96)$ sehingga $H 0$ ditolak (Ha diterima). Hal ini berarti lingkungan kerja berpengaruh signifikan terhadap kinerja dimediasi oleh kepuasan kerja pada kantor Dinas Ketahanan Pangan dan Peternakan Provinsi Sumatera Utara.

Lingkungan yang menyenangkan dan memberikan kinerja yang maksimal bagi karyawan. Karena pegawai tidak merasa terganggu dalam melaksanakan tugas-tugasnya.Sehingga mereka lebih tenang, aktif, tekun dan serius menghadapi tugas-tugasnya. Penciptaan lingkungan kerja yang menyenangkan dan dapat memenuhi kebutuhan pegawai akan memberikan kinerja yang maksimal dan mendorong semangat mereka. Sebaliknya lingkungan kerja yang kurang mendapat perhatian akan membawa dampak negatif dan menurunkan tugas mengalami gangguan, sehingga kurang semangat dan kurang mencurahkan tenaga dan pikirannya terhadap tugasnya.

Lingkungan kerja non-fisik seperti struktur tugas, desain pekerjaan, pola kepemimpinan, pola kerja sama dan budaya organisasi semakin baik, maka kepuasan kerja pun juga semakin membaik sehingga kinerja pegawai akan semakin meningkat. Berdasarkan penelitan terdahulu yang dilakukan oleh (Sinambela \& Tanjung, 2018), (Puspita, 2011), (Bahagia et al., 2018) menyimpulkan bahwa lingkungan kerja berpengaruh terhadap kinerja. 


\section{KESIMPULAN}

Berdasarkan hasil penelitian dan pembahasan yang telah dikemukakan sebelumnya maka dapat diambil kesimpulan dari penelitian mengenai "Pengaruh Dukungan Organisasi dan Lingkungan Kerja Terhadap Kinerja Pegawai Dimediasi Kepuasan Kerja Pada Dinas Ketahanan Pangan dan Peternakan Provinsi Sumatera Utara" adalah sebagai berikut :

1. Dukungan organisasi berpengaruh signifikan terhadap kinerja pegawai pada Dinas Ketahanan Pangan dan Peternakan Provinsi Sumatera Utara.

2. Lingkungan kerja berpengaruh signifikan terhadap kinerja pegawai pada Dinas Ketahanan Pangan dan Peternakan Provinsi Sumatera Utara.

3. Kepuasan kerja berpengaruh signifikan terhadap kinerja pegawai pada Dinas Ketahanan Pangan dan Peternakan Provinsi Sumatera Utara.

4. Dukungan organisasi berpengaruh signifikan terhadap kepuasan kerja pegawai pada Dinas Ketahanan Pangan dan Peternakan Provinsi Sumatera Utara.

5. Lingkungan kerja berpengaruh signifikan terhadap kepuasan kerja pegawai pada Dinas Ketahanan Pangan Dan Peternakan Provinsi Sumatera Utara.

6. Dukungan organisasi berpengaruh signifikan terhadap kinerja pegawai yang dimediasi kepuasan kerja pada Dinas Ketahanan Pangan dan Peternakan Provinsi Sumatera Utara.

7. Lingkungan kerja berpengaruh signifikan terhadap kinerja pegawai dimediasi oleh kepuasan kerja pada Dinas Ketahanan Pangan dan Peternakan Provinsi Sumatera Utara.

\section{DAFTAR PUSTAKA}

Abddurahmat, A. (2016). Manajemen Sumber Daya Manusia. Rineka Cipta.

Adhan, M., Jufrizen, J., Prayogi, M. A., \& Siswadi, Y. (2020). Peran Mediasi Komitmen Organisasi pada Pengaruh Kepuasan Kerja terhadap Kinerja Dosen Tetap Universitas Swasta di Kota Medan. Jurnal Samudra Ekonomi Dan Bisnis, 11(1), 1-15. https://doi.org/10.33059/jseb.v11i1.1654

Aruan, Q. S., \& Fakhri, M. (2015). Pengaruh Lingkungan Kerja Terhadap Kepuasan Kerja Karyawan Lapangan Departemen Grasberg. Modus, 27(2), 17-32.

Astuti, R., \& Iverizkinawati, I. (2018). Pengaruh Kepemimpinan dan Lingkungan Kerja Terhadap Kepuasan Kerja Karyawan Pada PT. Sarana Agro Nusantara Medan. Jurnal Ilman, 6(1), 26-41.

Bahagia, R., Putri, L. P., \& Rizdwansyah, T. (2018). Pengaruh Kepemimpinan Dan Lingkungan Kerja Terhadap Kinerja Karyawan Pada PT Pegadaian (Persero) Kanwil I Medan. Prosiding Seminar Nasional Vokasi Indonesia, 1, 100-105.

Bangun, W. (2012). Manajemen Sumber Daya Manusia. Erlangga.

Basuki, \& Susilowati, I. (2005). Dampak Kepemimpinan, dan Lingkungan Kerja, Terhadap Semangat Kerja. Jurnal JRBI, 1(1), 31-47.

Danish, R. Q., Ramzan, S., \& Farid, A. (2013). Effect of Perceived Orgarnizational Support and Work Environtment on Organizational Commitment; Mediating Role of Self Monitoring. Advances In Economic and Business, 1(4), 312-317.

Dawley, D., Jeffrey, D. H., \& Neil, S. B. (2010). Perceived Organizational Support and Turnover Intention: The Mediating Effects of Personal Sacrifice and Job Fit. The Journal of Social Psychology, 150(3), 238-257.

Defrionaldo, \& Rivai, H. A. (2019). Pengaruh Dukungan Organisasi dan Persepsi Keadilan Organisasional Terhadap Kinerja Dengan Organizationa; Citizenship 
Behavior Sebagai Variabel Mediasi: Studi Pada Karyawan Beacukai Pekanbaru. Jurnal Ilmiah Mahasiswa Ekonomi Manajemen, 4(3), 544-561.

Erdogan, B., \& Enders, J. (2007). Support from The Top: Supervisors' Perceived Organizational Support as a Moderator of Leader-Member Exchange to Satisfaction and Performance Relationship. Journal of Applied Psychology, 92(2), 321-330.

Fahmi, I. (2017). Manajemen Sumber Daya Manusia. Alfabeta.

Farisi, S., \& Fani, W. M. (2019). Influence of Work Environment and Work Dicipline on Employee performance. International Conference on Global Education VII, 6981.

Fattah, H. (2017). Kepuasan Kerja \& Kinerja Pegawai,Budaya Organisasi,Perilaku Organisasi Dan Efikasi Diri.

Handoko, H. (2000). Manajemen Personalia. BPFE.

Jerry, L. M., Tjoe, T. F., \& Naga. (2012). Analisis Pengaruh Lingkungan Kerja dan Pemberian Kompensasi Terhadap Kinerja Karyawan CV. Mum Indonesia. Binus Business Review, 3(1), 573-586.

Jufrizen, J. (2017). Efek Mediasi Kepuasan Kerja Pada Pengaruh Kompensasi Terhadap Kinerja Karyawan. Jurnal Ilmiah Manajemen \& Bisnis, 17(1), 1-17.

Jufrizen, J., Lumbanraja, P., Salim, S. R. A., \& Gultom, P. (2017). The Effect of Compensation, Organizational Culture and Islamic Work Ethic Towards the Job Satisfaction and the Impact on the Permanent Lecturers. International Business Management, 11(1), 53-60.

Jufrizen, J, \& Rahmadhani, K. N. (2020). Pengaruh Budaya Organisasi Terhadap Kinerja Pegawai Dengan Lingkungan Kerja Sebagai Variabel Moderasi. Jurnal Riset Manajemen Dan Bisnis Dewantara, 3(1), 66-79. https://doi.org/10.26533/jmd.v3i1.561

Luthans, F. (2012). Perilaku Organisasi. Penerbit Andi.

Mangkunegara, A. A. (2014). Evaluasi Kinerja Sumber Daya Manusia. Refika Aditama. Mangkuprawira. (2014). Manajemen Sumber Daya Manusia. Ghalia Indonesia.

Maryati, M. C. (2014). Manajemen Perkantoran Efektif. UPP STIM YKPN.

Mathis, R., \& Jackson, J. (2002). Manajemen Sumber Daya Manusia. Salemba Empat.

Milkovich, G. T., Newman, J. M., \& Gerthat, B. (2014). Compensation. McGraww-Hill.

Muis, M. R., Jufrizen, J., \& Fahmi, M. (2018). Pengaruh Budaya Organisasi Dan Komitmen Organisasi Terhadap Kinerja Karyawan. Jesya (Jurnal Ekonomi \& Ekonomi Syariah), 1(1), 9-25.

Nawawi, H. (2010). Perencanaan Sumber Daya Manusia Untuk Organisasi. UGM.

Nitisemito, A. S. (2010). Manajemen Personalia Manajemen Sumber Daya Manusia. Ghalia Indonesia.

Noor, A. (2013). Management Event. Alfabeta.

Pianda, D. (2018). Kinerja Guru: Kompetensi Guru, Motivasi Kerja, Kepemimpinan Kepala Sekolah. CV Jejak.

Puspita, D. R. (2011). Pengaruh Motivasi Kompetensi dan Lingkungan Kerja pada Kinerja Aparatur Penyuluh Keluarga Berencana. Jurnal Ilmu Administrasi Negara, 11(1), 86-96.

Putra, I. D. P. G. W., Sintaasih, D. K., \& Putra, M. S. (2016). Pengaruh Dukungan Organisasi Terdahap Kepuasan Kerja dan Komitmen Organisasional (Studi Pada Karyawan Outsorcing Depo Arsip PT X). E-Jurnal Ekonomi Dan Bisnis Universitas Udayana, 5(10), 3531-3560. 
Rasyid, M. A., \& Tanjung, H. (2020). Pengaruh Kompensasi, Lingkungan Kerja dan Motivasi Terhadap Kepuasan Kerja Guru pada SMA Swasta Perkumpulan Amal Bakti 4 Sampali Medan. Maneggio: Jurnal Ilmiah Magister Manajemen, 3(1), 60-74. https://doi.org/10.30596/maneggio.v3i1.4698

Rhoades, L., \& Eisenberg, R. (2008). Perceived Organizational Support: A Review of the Literature. Journal of Applied Psychology, 87(4), 698-714.

Riantoko, R., Sudibya, G. A., \& Sintaasih, D. K. (2017). Pengaruh Dukungan Organisasi Terhadap Motivasi Kerja dan Kinerja Anggota Polsek Kuta Utara. E-Jurnal Udayana, 6(3), 1-15.

Richard, D. L. (2012). Manajemen. Salemba Empat.

Rivai, V. (2014). Manajemen Sumber Daya Manusia Untuk Perusahaan. PT. Raja Grafindo Persada.

Rivai, Veithzal. (2014). Manajemen Sumber Daya Manusia Untuk Perusahaan (6th ed.). PT. Raja Grafindo Persada.

Robbins, S. P. (2012). Perilaku Organisasi. PT. Indeks Kelompok Gramedia.

Saputra, A. T., Bagia, L. W., \& Yulianthini, N. Y. (2016). Pengaruh kepuasan kerja dan loyalitas karyawan terhadap kinerja karyawan. E-Journal Bisma Universitas Pendidikan Ganesha Jurusan Manajemen, 4(6), 1-8.

Sedarmayanti. (2016). Manajemen Sumber Daya Manusia Reformasi Birokrasi Dan Manajemen Pegawai Negeri Sipil. PT. Refika Aditama.

Siagian, S. P. (2014). Manajemen dan Evaluasi Kinerja. Bumi Aksara.

Sinambela, E., \& Tanjung, H. (2018). Pengaruh Pelatihan, Kompetensi, Lingkungan Kerja Terhadap Kinerja Pegawai. Manggeio: Jurnal Ilmiah Magister Manajemen, 1(1), 46-58.

Sofyandi, H. (2008). Manajemen Sumber Daya Manusia. Penerbit Graha Ilmu.

Sudarmanto, S. (2011). Kinerja dan Pengembangan Kompetensi SDM. Pustaka Pelajar.

Sunyoto, D. (2013). Manajemen Sumber Daya Manusia. Center For Academic Publishing Servieces.

Sutrisno, E. (2010). Manajemen Sumber Daya Manusia. Erlangga.

Sutrisno, Edy. (2009). Manajemen Sumber Daya Manusia. Prenadamedia Group.

Syahputra, I., \& Jufrizen, J. (2019). Pengaruh Dilkat, Promosi dan Kepuasan Kerja Terhadap Kinerja Pegawai. Manggeio: Jurnal Ilmiah Magister Manajemen, 2(1), 104-116.

Tiffin, \& McCornick. (1997). Manajemen Sumber Daya Manusia. Salemba Empat.

Torang, S. (2013). Organisasi dan Manajemen (Perilaku, Struktur, Budaya \& Perubahaan Organisasi). Alfabeta.

Wagner, J. A., \& Hollenbeck, J. R. (2010). Organizational Behavior: Securing Competitive Advantage. Routledger.

Wayen, M. R. (2011). Human Resource Management. Erlangga.

Wibowo, M., Musadieq, M. A., \& Nurtjahjono, G. E. (2014). Pengaruh Lingkungan Kerja Terhadap Kepuasan Kerja (Studi Pada Karyawan PT. Telekominikasi Indonesia Tbk Kandatel Malang). Jurnal Administrasi Bisnis (JAB), 16(1), 1-9.

Wijaya, I. K. (2018). Pengaruh Kepuasan Kerja Terhadap Kinerja Karyawaan CV Bukti Sanomas. AGORA, 6(2), 1-5. 